\title{
Empati dalam Tradisi Membakar "Tunam" dan "Melemang" saat Malam Nujuh Likur pada Masyarakat Kabupaten Kaur
}

\author{
Lailatul Badriyah \\ Institut Agama Islam Negeri Bengkulu \\ Jalan Raden Fatah Pagar Dewa Kota Bengkulu \\ lailatulbadriyah@iainbengkulu.ac.id
}

\begin{abstract}
Abstrak: Empati dalam Tradisi Membakar "Tunam" dan "Melemang" Saat Malam Nujuh Likur Pada Masyarakat Kabupaten Kaur. Tulisan ini bertujuan untuk memahami konsep empati berbasis budaya dengan mengkaji salah satu kearifan lokal (local wisdom) di Kabupaten Kaur. Kearifan lokal yang diangkat adalah tradisi membakar tunam dan Melemang pada malam nujuh likur (27 Ramadhan) pada masyarakat Kabupaten Kaur. Empati diartikan sebagai kemampuan mental individu dalam merespok secara empatik atas kejadian dari kondisi atau situasi orang lain dengan cara merasakan dan berpikir yang sama dengan orang tersebut. Tunam adalah susunan batok kelapa yang disusun secara vertikal, sedangkan Melemangproses membuat makanan khas yang terbuat dari beras ketan dengan campuran santan dan garam lalu dibakar dan nantinya akan dimakan bersamasama dengan jiran tetangga dan sanak keluarga. Penelitian ini berjenis penelitian kualitatif dengan pendekatan etnografi dan kajian hermeneutika. Etnografi digunakan untuk memahami lebih mendalam pada konteks budaya sedangkan hermeneutika digunakan untuk mengkaji lebih dalam makna tunam dan melemang yang bukan hanya sekedar untuk penerangan semata. Dalam penelitian ini peneliti menggunakan teknik purposive sampling dalam menetapkan sampel. Hasil penelitian menunjukkan bahwa tradisi membakar tunam dan melemang memicu munculnya ingatan-ingatan masa lalu serta perasaan-peraasan yang melibatkan emosi yang mendalam (pada usia 40 ke atas). Adapun perasaan yang muncul antara lain perasaan senang, semangat, sedih dan kebanggan diri/harga diri (self esteem). Adapun pada sampel siswa yang berusia 15 tahun (remaja), secara istilah mereka tidak mengetahui apa sebenarnya tunam akan tetapi ketika peneliti mendeskripsikan bentuknya (simbolik), ekspresi yang muncul adalah seperti mendapatkan pengetahuan baru yang belum pernah diketahui sebelumnya.
\end{abstract}

Kata Kunci: Empati, Tunam, Melemang, Nujuh likur, Etnografi.

Abstact: Empathy in Tradition of Burning "Tunam" and "Melemang" During the Night of the Seven Likur in the People of Kaur Regency. This study aims to understand the concept of cultural-based empathy by examining one of the local wisdom in Kaur Regency. Local wisdom raised is the tradition of burning "tunam" and "weakened" on the seventh night of porridge (27 Ramadan) in the people of Kaur Regency. Empathy is defined as an individual's mental ability to respond empathetically to the events of another person's condition or situation by feeling and thinking the same as that person. "Tunam" is arrangement of coconut shells arranged vertically, while the "Melemang" process of making a special food made from glutinous rice with a mixture of coconut milk and salt then burned and later will be eaten together with neighboring neighbors and relatives. This research is a qualitative research with ethnographic approach and hermeneutics study. Ethnography is used to understand more deeply the cultural context while hermeneutics is used to examine more deeply the meaning of "tunam" and "Melemang" which is not just for lighting alone. In this study, researchers used purposive sampling technique in setting samples. The results showed that the tradition of burning "tunam" and "Melemang" triggered the emergence of memories of the past as well as feelings that involved deep emotions (at the age of 40 and above). The feelings that arise include feelings of pleasure, enthusiasm, sadness and pride (self esteem). As for the sample of students aged 15 years (adolescents), in terms they do not know what exactly "tunam" but when researchers describe the shape (symbolic), the expression that appears is like getting "new knowledge" that has never been known before.

Keyword: Empathy, Tunam, Melemang, Nujuh likur, ethnographic. 


\section{Pendahuluan}

"Empathy defined as an affective response more appropriate to another's situation than one's own". Pernyataan tersebut menyatakan bahwa empati didefinisikan sebagai respon afektif (perasaan) terhadap situasi orang lain dari pada situasi diri sendiri." Secara lebih mendalam, pengertian ini menjelaskan bahwa empati menitikberatkan lebih kepada respon afektif dari pada kemampuan kognitif seseorang. Respon afektif ini sangat cepat dalam mendeteksi pikiran dan perasan orang lain. ${ }^{1}$

Hoffman mengidentifikasi terdapat lima bentuk pembangkitan empati, antara lain sebagai berikut:

a. Primitive (mimicry) artinya peniruan.

Peniruan ini memiliki dua tahapan, seseorang yang secara spontan meniru wajah, suara ataupun ekspresi-ekspresi perasaan yang membuat sebuah perubahan. Perubahan ini memicu kerja otak yang selanjutnya menghasilkan perasaan-perasaan (feelings) yang menyerupai perasaan orang lain.

b. Otomatis pada classical conditioning. Respon yang terkondisikan untuk menekan pikiran-pikiran dengan cara mengobservasi orang lain pada saat individu sedang mengalami tekanan (distress).

c. Preverbal yaitu hubungan langsung pada isyarat-isyarat dari orang lain berupa situasi yang mengingatkan individu pada pengalaman-pengalaman masa lalu yang memunculkan perasaanperasaan (feelings) baik itu perasaan positif maupun negatif.

d. Bahasa verbal yang ditandai dengan mengkomunikasikan kondisi individu yang tertekan (distress) dengan pengalaman-pengalaman masa lalu yang menyakitkan. e. Perspective Taking yaitu membayangkan bagaimana seandainya kondisi orang yang menjadi fokus (observee) terjadi dan dirasakan oleh individu yang bersangkutan (perceiver).

Selain Hoffman, terdapat teori empati multidimensi yang dikemukakan oleh Davis tahun 1983. Davis menguraikan empat konstruk empati dalam satu episode empati yang terangkum dalam sebuah proses empati yaitu antecedents, processes, intrapersonal outcomes, interpesonal outcomes. Keempat konstruk tersebut kemudian diuraikan lagi menjadi 4 aspek multidimensional yaitu perspective taking dan fantasy mewakili kognitif, serta empathic concern dan personal distress mewakili afektif.

\section{Empati dan Emosi}

Dalam kajian Psikologi, emosi adalah reaksi penilaian baik positif ataupun negatif yang kompleks melibatkan rangsangan yang datang dari luar maupun dari dalam ke dalam sistem saraf, berbagi emosi biasanya berhubungan dengan pola pengalaman (internal), subjektif (relative), perilaku overt (menangis atau tertawa), motivasi (ingin mendekat atau menjauh), proses fisiologis (tekanan darah, adrenalin, dll), proses belajar dan kondisi sistem saraf seseorang. ${ }^{2}$

Dalam konsep empati, Davies mengemukakan Istilah "penularan emosi" yang merupakan sebuah fenomena untuk membagikan ekspresi emosi yang kuat sehingga orang-orang yang berada di sekitar individu memiliki aliran emosi yang sama. Contohnya ketika seseorang berkumpul dengan kelompok yang gampang untuk tertawa (humoris) maka seseorang tersebut mungkin akan ikut tertawa tanpa mengetahui sebab awal dia tertawa, sebaliknya ketika seseorang berada pada kondisi yang membuatnya panik, 
maka orang tersebut akan memunculkan ekspresi kecemasan dan kepanikan dari kondisi yang sedang dihadapinya. ${ }^{3}$

\section{Empati dan Budaya}

Taylor mendefinisikan kebudayan sebagai sebuah satu kesatuan kompleks yang meliputi ilmu pengetahuan, kepercayaan, kesenian, akhlak, hukum, adat, dan banyak kemampuan-kemampuan dan kebiasaankebiasaan lain yang diperoleh manusia sebagai anggota masyarakat. Kebudayaan bisa dicapai dengan belajar dan sebagai hasil belajar yang dibiasakan antar anggota suatu masyarakat. ${ }^{4}$

Menurut Linton, "A culture is the configuration of learned behavior and results of behavior whose component elements are shared and transmitted by the members of a particular society" bahwa kebudayaan merupakan konfigurasi dari tingkah laku yang dipelajari dan hasil tingkah laku yang unsur-unsurnya digunakan bersama-sama dan ditularkan oleh para warga masyarakat. Kebudayaan berkenaan dengan keseluruhan cara hidup anggota-anggota masyarakat. Kebudayaan meliputi bagaimana mereka berpakaian, adat kebiasaan perkawinan mereka, kehidupan keluarga, pola-pola kerja mereka, upacara-upacara keagamaan, dan pencarian kesenangan. Kebudayaan meliputi juga barang-barang yang mereka ciptakan dan yang bermakna bagi mereka, seperti busur dan anak panah, bajak, pabrik dan mesin, komputer, buku, tempat kediaman. ${ }^{5}$

Menurut Honigmann ada tiga gejala kebudayaan yaitu ideas, activities, dan artifacts. Sehingga Koentajraningrat menyimpulkan wujud kebudayaan ada tiga macam: 1) kebudayaan sebagai kompleks ide, gagasan, nilai, norma, dan peraturan; 2) kebudayaan sebagai suatu kompleks aktivitas kelakuan berpola manusia dalam masyarakat; dan 3) benda-benda sebagai karya manusia. Menurut Koentjaraningrat nilai budaya terdiri dari konsepsi-konsepsi yang hidup dalam alam fikiran sebagian besar warga masyarakat mengenai hal-hal yang mereka anggap amat mulia. Sistem nilai yang ada dalam suatu masyarakat dijadikan orientasi dan rujukan dalam bertindak. Oleh karena itu, nilai suatu budaya yang dimiliki oleh seseorang mempengaruhinya dalam menentukan alternatif, cara-cara, alat-alat, dan tujuantujuan pembuatan yang tersedia. ${ }^{6}$

Salah satu peneliti tentang keterkaitan empati dan budaya adalah Wangdkk, yang menyatakan bahwa untuk melihat orang lain harus melibatkan pengaruh dari budaya mereka. Dilakukan secara mendalam untuk memahami bagaimana orang tersebut mempersepsikan sesuatu yang dipengaruhi oleh budayanya. Ada juga pandangan yang menyatakan bahwa semua perilaku, tindakan, dan aktifitas psikologis manusia berlangsung dalam sebuah konteks sosial-budaya. Hal ini menunjukkan bahwa usaha yang dilakukan seseorang untuk memahami pikiran orang lain merupakan aktifitas yang dimediasi secara kultural (budaya).

Pengalaman empati terbagi menjadi dua arah yaitu, dari objek menuju seni melalui pikiran seniman, dan dari seni menuju pengamat, melalui perenungan terhadap karya seni. Pengalaman estesis merupakan pengalaman empati, kondisi saat pengamat beresonansi dengan melihat dan merasakan sesuatu (perasaan) dari karya/seni tersebut. Dengan kata lain, terlibat secara emosional (perasaan) dalam sebuah kesenian budaya berarti bagian dari sebuah pengalaman empati bersifat estesis (esthetic empathy) yang berisi tentang proses persepsi, pemahaman, pemaknaan dan penafsiran. ${ }^{7}$

Perwujudan dari kesenian dalam sebuah tradisi dapat dijadikan sebuah media yang 
Tsaqufah \& Tarikh: Jurnal Kebudayaan dan Sejarah Islam

Vol. 5 №. I Januari-Juni 2020

dapat dilihat, didengar, dan dirasakan. Ketika kesenian sedang dimainkan dapat membangkitkan ingatan emosional, yang terlihat dari ekspresi-ekspresi emosi. Menurut Strayer ketika seseorang mampu melaporkan emosi-emosi apa saja yang muncul ketika mereka sedang menikmati sebuah karya seni, baik secara kognitif dan afektif memang tidak langsung memunculkan empati, tetapi individu akan melakukan berbagi emosi dengan orang lain (Share Emotion). ${ }^{8}$

\section{Interaksi Simbolik}

Komunikasi yang berlangsung dalam tatanan interpersonal tatap muka dialogis timbal balik dinamakan interaksi simbolik (Symbolic Interaction). Interaksi simbolik telah menjadiistilahkomunikasi dansosiologiyang bersifat interdisipliner. Objek materialnya pun sama, yaitu manusia, dan perilaku manusia (human behavior). ${ }^{9}$ Komunikasi merupakan proses sosial individu-individu menggunakan simbol-simbol untuk menciptakan dan menginterpretasi makna dalam lingkungannya sendiri. Interaksi simbolik menurutperspektifinteraksional,merupakan salah satu perspektif yang ada dalam studi komunikasi, yang bersifat "humanis".

Menurut Ardianto, perspektif ini sangat menonjolkan keagungan dan maha karya nilai individu di atas pengaruh nilainilai yang ada selama ini. Perspektif ini menganggap setiap individu di dalam dirinya memiliki esensi kebudayaan, berinteraksi di tengah sosial masyarakatnya, dan menghasilkan makna "buah pikiran" yang disepakati secara kolektif. Dan pada akhirnya, dapat dikatakan bahwa setiap bentuk interaksi sosial yang dilakukan oleh setiap individu, akan mempertimbangkan sisi individu tersebut, inilah salah satu ciri dari perspektif interaksional yang beraliran interaksionisme simbolik. Teori interaksi simbolik menekankan pada hubungan antara simbol, interaksi, dan individu itu sendiri. ${ }^{10}$

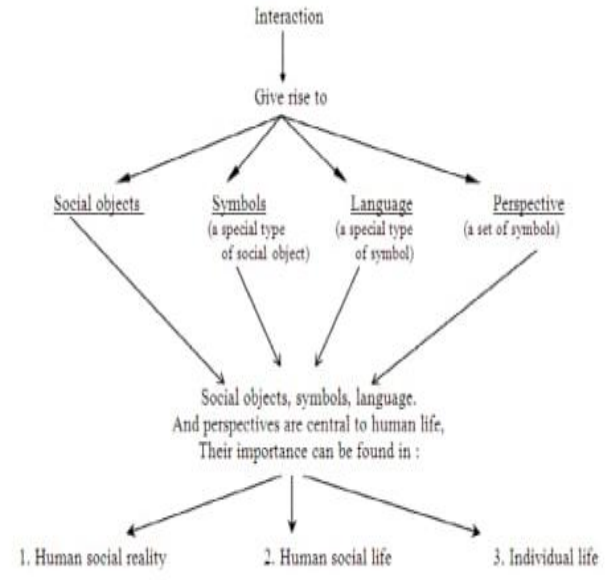

\section{Gambar 1. Proses Interaksi dalam Masyarakat Menurut Charon"11}

Gambar di atas memperlihatkan bahwa pola interaksi terbentuk secara simbolik meliputi bahasa, objek sosial, lambanglambang, dan berbagai pandangan. Blumer dalam Ahmadi (2008) mengembangkan lima konsep dasar dalam interaksi simbolik, antara lain sebagai berikut:

a. Konsep Diri (self)

b. Konsep Perbuatan (actions)

c. Konsep Objek (object)

d. Konsep interaksi sosial (social interaction)

e. Konsep tindakan bersama (join action)

Dalam mencermati berbagai hal yang terjadi di masyarakat zaman sekarang, muncul terjadinya kemunduran moral dan sarkastis dalam berperilaku. Hal ini sangat terlihat menonjol dalam setiap aspek kehidupan masyarakat, karena tidak terinternalisasinya nilai-nilai dan makna dari tradisi/budaya leluhur yang bernilai positif dan mulai ditinggalkan karena arus globalisasi. Berbagai dampak negatif dari globalisasi adalah lunturnya semangat gotong royong, solidaritas, kesetiakawanan, dan kepedulian, karena seseorang lebih cenderung untuk menjadi diri yang individualis. Tentu saja hal ini 
dapatmenjadiancamanterbesarbagibangsa Indonesia yang dituntut untuk menjadi diri yang berkarakter, berdasarkan ideologi bangsa Indonesia yaitu pengamalan nilainilai Pancasila dalam kehidupan rakyat Indonesia.

Budaya lokal memiliki unsur-unsur kebijaksanaan, kearifan, dan kebaikan yang mampu menguatkan diri individu ketika menghadapi tantangan seperti, masuknya budaya asing. Kearifan lokal sendiri merupakan bagian dari budaya masyarakat yang diwariskan secara turun temurun, dan dari generasi ke generasi secara lisan berupa permainan, syair, pantun, cerita rakyat, serta aktivitas kesenian lainnya. Nilai-nilaikearifanlokalmampumemegang kendali dan mengarahkan perkembangan kebudayaan yang merupakan manifestasi dari kepribadian yang tercermin dalam sikap dan pola tingkah laku sehari-hari.

Tradisi malam nujuh likur merupakan tradisi yang dilakukan secara turun temurun di masa lalu oleh masyarakat Islam Melayu dengan menyalakan lampu atau penerangan tradisional yang ditempatkan di sekitaran masjid, pinggiran jalan, halaman rumah, dan teras-teras rumah penduduk. Seperti yang kita ketahui bahwa penyebaran Islam ke Bengkulu sangat dipengaruhi oleh orang-orang Melayu yang kental akan tradisi dan budaya dalam menyebarkan ajaran Islam. Terdapat dua alasan mengapa tradisi tersebut dinamakan nujuh likur, yang pertama di malam itu biasanya orang-orang Melayu dahulunya berbondong-bondong datang menemui tok imam untuk membayar zakat fitrah mereka. Kedua, malam 27 Ramadan itu berdasarkan penjelasan dan pengalaman para ulama terdahulu bahwa, mereka sering menemukan malam Lailatul Qadar di saat malam nujuh likur tersebut. ${ }^{11}$

Banyak kegiatan yang dilakukan oleh masyarakat Kaur pada malam nu- juh likur, diantaranya membuat tunam, semacam penerangan yang terbuat dari tempurung/batok kelapa kering yang disusun secara vertikal dan diujungnya diberi bambu, setelah itu di bakar hingga batok kelapa habis menjadi arang. Terdapat perbedaan penamaan dari penerangan tersebut, di Bintan terkenal dengan nama lampu cangkok. Hakikatnya sama yaitu ingin menjelaskan tentang penerangan tradisional (pelita) untuk menerangi malam nujuh likur tesebut. Zaman dahulu selain menyalakan Tunam, pelaksanaannujuhlikur dilengkapi dengan berbagai kegiatan oleh masyarakat, antara lain membuat Lemang dan Tapai. Lemang adalah makanan khas dari Kaur yang terbuat dari beras ketan yang dimasak dengan campuran garam dan santan, kemudian dimasukkan ke dalam bambu dan dibakar. Adapun Tapai merupakan makanan pendamping dari lemang yang terbuat dari ketan hitam yang difermentasikan dengan menggunakan ragi.

Kegiatan menyalakan tunam dan membuat lemang sebenarnya memiliki makna filosofi yang sangat mendalam. Relevansi yang dapat penulis jelaskan terkait kegiatan tersebut dengan kajian psikologiyaitu unsur-unsurpsikologisyang terkandung dalam kegiatan tersebut. Nilainilai positif yang terkandung seperti sikap gotong royong, merasakan kebersamaan, menjalin kekompakan dan kerjasama, serta menumbuhkan rasa syukur atas segala rizki yang didapat dengan doa selamat. Terkhusus kajian dalam pembentukan karakter bagi anak-anak, kegiatan tunam dan melemang memberikan makna yang mendalam dalam menanamkan nuansa Islami sejak dari kecil, dan hal itu biasanya lebih melekat dan selalu menjadi ingatan bagi mereka setelah dewasa dalam menjalani kehidupan.

Tradisi nujuh likur juga kental dengan 
nilai-nilai moral dan spiritual. Lampu tunam seharusnya mengingatkan bahwa Ramadhan segera berakhir, maka sebagai umat Islam hendaknya lebih meningkatkan ibadah kepada Allah SWT. Terlebih pada malam ganjil karena pada malam itulah diyakini masyarakat datangnya Lailatul Qadar. Oleh karenanya, tradisi itu menjadi simbol. Dalam artian ketika diyakini bahwa penghujung Ramadhan tepatnya ketika umat Islam menanti atau menunggu datangnya Lailatul Qadar. Secara psikologis, emosi yang muncul ketika seseorang mampu memaknai tradisi Nujuh likur tersebut ialah perasaan gembira karena akan menyambut hari raya idul fitri yang hakikatnya adalah manusia kembali kepada keadaan yang fitrah, terhapusnya dari dosa-dosa, serta gembira karena telah dapat melewati puasa selama 1 bulan lamanya. Akan tetapi di sisi lain, ada perasaan sedih yang muncul karena berpisah dengan bulan Ramadhan dan berpikir apakah nanti dapat bertemu kembali dengan bulan puasa di tahun yang akan datang.

Pergeseran antara budaya tradisional dengan budaya modern telah terjadi di era globalisasi, sehingga tanpa kita sadari adat istiadat kita yang luhur terkikis sedikit demi sedikit berganti dengan budaya modern yang lebih gaul. Seperti yang diungkapkan oleh Abdullah bahwa suatu kebudayaan bagaimanapun tidak dapat dilepaskan begitu saja dari ruang, kebudayaan itu bisa saja dibangun, dipelihara, dan dilestarikan, atau bahkan diubah. Persoalan yang penting ialah ruang yang menjadi wadah tempat kebudayaan itu berada, telah mengalami redefinisi sejalan dengan tumbuhnya kota dan gaya hidup modern, yang secara langsung diawali dengan perubahan rancangan ruang. ${ }^{12}$ Di Kaur saat ini penerangan telah merata di seluruh pinggiran kota, arus globalisasi akhirnya sedikit demi sedikit memberikan kemudahan dan kelayakan bagi masyarakat Kaur. Hal ini berdampak pada mulai ditinggalkannya tradisi malam nujuh likur, salah satunya tidak lagi membakar tunam di malam hari.

Menurut hasil observasi prapenelitian, penulis dapat menjelaskan bahwa banyak dari masyarakat Kaur yang tidak mengetahui istilah Malam nujuh likur, kata tunam khususnya di kalangan remaja. Mereka mengetahui bentuk dari tunam itu sendiri ketika penulis mendeskripsikan bentuk tunam akan tetapi tidak mengetahui nama dari benda tersebut. Ketika penulis menanyakan kepada partisipan, mereka menjawab bahwa sedari kecil mereka tidak diperkenalkan dengan istilah tersebut. Akan tetapi, ketika saat akhir bulan puasa mereka secara tradisi membakar tunam tersebut tanpa tahu makna dari kegiatan tersebut.

Lain halnya ketika penulis mewawancarai tetuhe (orang-orang tua) yang sejak lama memaknai kegiatan tersebut. Penulis menemukan emosi-emosi positif yaitu unsur-unsur kebahagiaan ketika mereka menceritakan bagaimana mereka dahulu mulai dari mengumpulkan sayak (batok kelapa). Perasaan suka cita, penuh dengan persaingan dan tantangan terutama ketika malam nujuh likur telah tiba. Dalam kajian psikologi, emosi diartikan sebagai reaksi penilaian atau ekspresi dari perilaku yang merupakan kombinasi kompleks antara perasaan individu dan rangsangan dari luar diri individu seperti pengalaman subjektif, perilaku overt, motivasi, fisiologis, dan pengaruh kepada sistem saraf. Ketika seseorang menerima rangsangan secara otomatis akan memunculkan primary emotion (emosi dasar) manusia yang terdiri dari emosi cinta, senang, marah, sedih, dan takut. Lima emosi dasar ini mendorong untuk memunculkan perilaku-perilaku 
tertentu misalnya perasaan cinta yang akan membuat kita menghargai orang yang kita cintai, perasaan senang membuat kita penuh dengan gairah, puas, bangga, serta percaya diri, sedangkan perasaan takut membuat kita cemas, penuh penyesalan, bingung, berharap, dan lain sebagainya. ${ }^{13}$ Untuk menjelaskan keterkaitan antara kegiatan malam nujuh likur dengan kajiankajian psikologi khususnya tentang tema empati, memang tidak akan langsung tertuju kepada empati, akan tetapi runtutan awal terbentuknya empati akan terlihat ketika menyandingkan antara budaya terkait dengan emosi dan penalaran moral. Moral dan empati merupakan dua hal yang tidak dapat terpisahkan. Penelitian ini menggunakan salah satu teori dari Hoffman tentang keterkaitan antara empati dan moral.

Selama beberapa dekade, Martin L. Hoffman telah tertarik pada perkembangan sosial dan emosional, khususnya hubungan perkembangan empati dan moral. Hoffman memandangempatisebagaisumbermotivasi prososial.Dalammenjelaskan model teoritis empati,Hoffmanmenggambarkan interaksi antara proses kognitif dan afektif dalam respon-respon empati seperti prososial, altruistik, dan bentuk moralitas secara lebih luas. Dia berasumsi bahwa empati dan prinsip-prinsip moral saling melengkapi untuk menghasilkan perilaku moral. Empati merupakan awal dari motivasi untuk bertindak secara moral sementara prinsip-prinsip moral mengurangi bias empatik dan empati berlebihan. Kajian penting dalam penelitian ini juga dijelaskan oleh Hoffman, bahwa terdapat proses psikologis yang terlibat dalam interaksi empati dengan perilaku orangtua tertentu, yang mendorong internalisasi moral pada anak-anak dan proses psikologis yang terlibat dalam hubungan empati dengan prinsip-prinsip moral abstrak.
Tujuan khusus tulisan ini adalah untuk memahami perkembangan empati yang berakar dari budaya salah satunya dari tradisi nenek moyang yaitu kegiatan membakar tunam dan melemang pada malam Nujuh likur di Kabupaten Kaur.

\section{Metode}

\section{Jenis penelitian}

Jenis penelitian ini adalah penelitian kualitatif yang pada dasarnya beru-pa interpretasi. Seorang peneliti menginterpretasikan data dengan mendeskripsikan subjek dan latar penelitian, menemukan tema-tema atau kategori, dan akhirnya menginterpretasi maknanya, baik makna secara personal maupun secara teoritis, mengemukakan hal-hal unik yang ditemukan serta menawarkan pertanyaanpertanyaan lanjutan. ${ }^{14}$

\section{Pendekatan Penelitian}

Pendekatan penelitian menggunakan pendekatan etnografi dan pendekatan hermeneutika. Dalam penelitian ini penulis menerapkan dua pendekatan etnografi untuk mendapatkan pemahaman tentang tradisi membakar tunam dan melemang, sedangkan pendekatan hermeneutika untuk menggali lebih dalam makna filosofis yang terkandung dari istilah tunam dan melemang.

Pendekatan etnografi yaitu metode yang membahas tentang ilmu penulisan suku bangsa, menggunakan bahasa yang kontemporer, dalam hal ini metode etnografi adalah metode yang menangkap secara langsung sudut pandang yang asli. Pada penelitian ini peneliti melibatkan dirinya dalam masyarakat tertentu untuk mendapatkan data yang diperoleh dengan cara mengamati, bertanya, dan mendengarkan baik itu yang dilihat maupun yang dibicarakan orang. Spradley menjelaskan bahwa etnografi adalah upaya untuk memperhatikan makna-makna tindakan darikejadianyang menimpa orang 
yang ingin kita pahami. Beberapa makna tersebut terekspresikan secara langsung dalam bahasa, dan di antara makna yang diterima, banyak yang disampaikan hanya secara tidak langsung melalui kata-kata dan perbuatan. Tujuan dari penelitan etnografi disampaikan Malinowski adalah mendeskripsikan dan membangun struktur sosial dan budaya suatu masyarakat untuk memahamisudut pandang pendudukasli. ${ }^{15}$ Berdasarkan pendapat tersebut, maka kita perlu mendefinisikan konsep kebudayaan dengancaramencerminkan tujuanetnografi tersebut. Pada situasi seperti ini, peneliti bukan hanya melakukan wawancara kepada informan, tetapi yang lebih penting lagi adalah melakukan observasi sambil berpartisipasi dalam kehidupan masyrakat. Dalam hal ini disimpulkan bahwa penelitian etnografi merupakan penelitian untuk memahami cara orangorang berinteraksi dan bekerjasama melalui fenomena yang teramati dalam kehidupan sehari-hari, yang bertujuan untuk mendeskripsikan, menganalisis, dan menafsirkan pola budaya suatu kelompok dalam hal perilaku, kepercayaan, bahasa, dan pandangan yang dianut bersama.

Pendekatan hermeneutika adalah metode pemaknaan yang diterapkan untuk memaknai suatu objek. Secara etimologis, kata hermeneutika berasal dari bahasa Yunani, hermeneuein yang berarti menafsirkan. Menurut Hardiman konsep hermeneutika menitikberatkan kepada metode atau cara yang digunakan untuk memaknai suatu teks sesuai dengan prosedur penafsiran yang baku. Pemikiran hermeneutika diawali dengan skeptisisme dan refleksi kritis terhadap praktik-praktik yang telah ada sebelumnya. ${ }^{16}$

\section{Subjek Penelitian}

Subjek penelitian ini melibatkan warga di Kabupaten Kaur tepatnya di Desa Tanjung Iman Kecamatan Kaur Tengah
Kabupaten Kaur.

\section{Teknik Pengambilan Subjek}

Sampel yang digunakan dipilih secara purposive sampling. Menurut Arikunto teknik mengambil sampel dengan tidak berdasarkan random, daerah atau strata, melainkan berdasarkan atas adanya pertimbangan yang berfokus pada tujuan tertentu. Berdasarkan kriteria yang dipertimbangkan, informan dalam penelitian ini adalah:

a) Penduduk asli masyarakat Kaur

b) Memiliki pengetahuan dan pengalaman tentang tradisi malam nujuh likur, tunam dan melemang

c) Usia 15-88 tahun

\section{Teknik Pengumpulan Data}

Teknik pengumpulan data yang digunakan dalam penelitian ini adalah:

\section{a) Pengamatan (observasi)}

Observasi hakikatnya merupakan kegiatan dengan menggunakan pancaindera, bisa penglihatan, penciuman, pendengaran, untukmemperolehinformasi yang diperlukan untuk menjawab masalah penelitian. Bungin mengemukakan beberapa bentuk observasi, yaitu: 1) observasi partisipasi, 2) observasi tidak terstruktur, dan 3) observasi kelompok. Berikut penjelasannya: 1) Observasi partisipasi adalah (participant observation) adalah metode pengumpulan data yang digunakan untuk menghimpun data penelitian melalui pengamatan penginderaan, peneliti terlibat dalam keseharian informan. 2) Observasi tidak terstruktur adalah pengamatan yang dilakukan tanpa menggunakan pedoman observasi, sehinggapenelitimengembangkan pengamatannyaber-dasarkanperkembangan yang terjadi di lapangan. 3) Observasi kelompok adalah pengamatan yang dilakukan oleh sekelompok tim peneliti terhadap sebuah isu yang diangkat menjadi objek penelitian. 
Kegiatan observasi penelitian ini akan dilakukan di Desa Tanjung Iman Kecamatan kaur Tengah Kabupaten Kaur. Selanjutnya pada kegiatan observasi ini, peneliti secara langsung membaur dengan kondisi masyarakatan dengan melihat fenomena-fenomena sosial yang terjadi di masyarakat.

\section{b) Teknik Wawancara}

Wawancara ialah proses komunikasi atau interaksi untuk mengumpulkan informasi dengan cara tanya jawab antara peneliti dengan informan atau subjek penelitian. Pada teknik wawancara yang dilakukan ini merupakan salah satu teknik pengumpulan data yang banyak digunakan dalam penelitian etnografi. Melalui teknik wawancara yang dilakukan secara lisan dalam pertemuan dengan narasumber secara individual, wawancara ditujukan untuk memperoleh data secara deskriptif dari narasumber yang dilaksanakan secara indvidu. Teknik wawancara yang dilakukan oleh peneliti pada penelitian ini ada dua, yaitu secara terarah (directed) dan tidak terarah (non directed) yang dilakukan secara terbuka dan mendalam. Pada teknik wawancara terarah peneliti perlu menyiapkan instrumen penelitian berupa daftar tujuh pertanyaan yang berguna untuk menggali informasi tentang halhal yang berhubungan dengan kegiatan malam nujuh likur (membakar tunam dan melemang). Sedangkan, pada teknik wawancara tidak terarah pertanyaan akan muncul ketika wawancara sedang berlangsung untuk menggali informasi yang lebih. Wawancara tidak terarah (non directed) merupakan wawancara yang bersifat terbuka, artinya peneliti memberikan kesempatan sebesar besarnya kepada informan untuk memberikan keterangan, sedangkan wawancara terarah (directed) adalah wawancarayang dilakukan berdasarkan daftar pertanyaan yang sudah disusun sebelumnya dalam bentuk yang sudah ditulis dan bersifat tertutup, artinya jawaban yang diberikankan sudah dibatasi yang relavan saja.

\section{c) Catatan Lapangan}

Teknik catatan lapangan merupakan alat yang sangat penting dalam penelitian kualitatif. Catatan lapangan adalah catatan yang dibuat peneliti dalam sebuah penelitian etnografi dari lapangan. Catatan tersebut dapat bersifat deskriptif (sesuai yang teramati) atau reflektif (mengandung penafsiran peneliti). Teknik menggunakan catatan lapangan meliputicatatan hasil wawancara dari informan mengenai tradisi malamnujuhlikur denganmembakartunam dan melemang, dan survei peneliti terhadap keadaan di lapangan. Proses pencatatan ini dilakukan dengan cara mencatat keseluruhan teks-teks yang diucapkan informan pada teknik wawancara dan apa saja yang dilihat ketika saat melakukan observasi. Tujuan dari penggunaan catatan lapangan ini adalah untuk mendapatkan data secara tertulis agar saat menganalisis data akan lebih mudah dilakukan.

\section{d) Dokumentasi}

Dokumentasi merupakan teknik pengumpulan data berupa sumber tertulis atau dokumen dari narasumber atau tempat narasumber melakukan kegiatan. Pada teknik ini, peneliti menggunakan kamera sebagai alat untuk mengambil foto selama proses wawancara. Tujuannya adalah untuk memperkuat data yang sudah didapatkan.

\section{Teknis Analisis Data}

Teknik analisis data yang digunakan dalam penelitian etnografi adalah teknik analisis interaktif etnografi, dalam upaya mendeskripsikan secara menyeluruh karakteristik kultural yang mempengaruhi perilaku sosial individu. Hal ini didukung dengan pendapat Endraswara bahwa analisis data penelitian kualitatif dapat 
dilakukan secara deskriptif etnografi atau yang lain. ${ }^{8}$ Analisis semacam ini berusaha mendeskripsikan subjek penelitian dan cara mereka bertindak serta berkata-kata. Adapun langkah-langkah yang dilakukan pada teknik analisis data ini adalah:

a) Mentranskripsi data yang disampaikan oleh narasumber yang dicatat ketika melakukan observasi dan wawancara.

b) Menerjemahkan data yang diperoleh. Untuk mempermudah peneliti dalam pengolahan data, maka data yang diperoleh harus diterjemahkan ke dalam bahasa Indonesia karena informasi yang diperoleh melalui wawancara dan observasi masih menggunakan bahasa kaur.

c) Mengidentifikasi dan menganalisis data. Pada tahap ini, peneliti akan mengidentifikasi data untuk mendapatkan makna tekstual. Peneliti melakukan identifikasi makna secara kontekstual.

d) Membuat kesimpulan. Pada tahapan ini peneliti membuat kesimpulan yang dilakukan secara keseluruhan dari hasil memaknai tradisi malam nujuh likur.

Uji keabsahan data atau uji validitas meliputi:

a) Uji Kredibilitas Data (Validasi Internal)

b) Uji Depenabilitas (Reliabilitas)

c) Uji Transferebilitas (Validitas Eksternal )

d) Uji Konfirmabilitas (Objektifitas).

Uji kredibilitas menjadi fokus utama dalam penelitian ini. Uji kredibilitas dilakukan dengan cara perpanjangan pengamatan, meningkatkan ketekunan, triangulasi, diskusi dengan teman sejawat, membercheck, dan analisis kasus negatif. Dalam penelitian ini, metode triangulasi yang digunakan peneliti adalah pemeriksaan melalui sumber. Membandingkan dan mengecek balik derajat kepercayaan suatu informasi yang diperoleh dari sumber yang berbeda.

\section{Hasil dan Pembahasan}

\section{Gambaran Kabupaten Kaur}

Bintuhan adalah ibu kota Kabupaten Kaur yang menurut cerita Bintuhan berasal dari kata "bintu'an". Awal munculnya kata "bintu'an" di daerah tersebut berasal dari kondisi masyarakat pada masa itu. Pada masa dahulu masyarakat terserang wabah penyakit bintuk (pilek), penyebarannya hampir ke seluruh kewedanan Kaur (zaman Belanda) sehingga masyarakat menyebutnya penyakit bintuk. Berawal dari sinilah oleh masyarakat setempat sering disebut-sebut sehingga mengalami perubahan dalam pengucapan dan menjadi kata bintuhan. Orang luar yang hendak ke sini juga menyebutnya "hendak ke Bintuhan",lamakelamaanlidahmasyarakat semakin mahir mengucapkannya dan akhirnya menjadi Bintuhan (Ernatip, 2011)

\section{Tradisi Membakar Tunam dan Melemang}

Tradisi malam nujuh likur adalah tradisi yang dilakukan oleh warga secara rutin setahun sekali saat bulan Ramadhan yaitu tepatnya pada tanggal 27 Ramadhan. Malam 27 Ramadhan dianggap masyarakat Kaur sebagai malam yang suci, masyarakat Kaur memasang tunam atau batok kelapa yang disusun vertikal kemudian bagian ujung atas diberi sumbu yang terbuat dari bambu dan akhirnya dibakar. Tunam tersebut dipasang di depan rumah warga, di sepanjang jalan di masing-masing tempat. Masyarakat memercayai bahwa malam nujuh likur ini malam turunnya Lailatul Qadar. Jadi setiap rumah harus terang benderang, supaya Lailatul Qadar bisa masuk kedalam rumah jika rumah kita terang. Kegiatan malam nujuh likur 
dilaksanakan dengan memasang tunam (batok kelapa), di Bengkulu Selatan dikenal dengan lunjuk pada tradisi Api Jagau dan di Bintan di kenal dengan sebutan lampu colok. Dahulu, Malam Nujuh Likur di Kaur dimeriahkan dan dirayakan dengan bermacam-macam kegiatan seperti membuat makanan berupa lemang, sejenis makanan yang terbuat dari beras ketan dicampur dengan santan dan garam kemudian dimasukkan ke dalam bambu lalu dibakar. Pada malam 27 Ramadhan tersebut masing-masing rumah warga menghidupkan/membakar tunam dan membuat melemang. Mereka beramai-ramai keluar dari rumah dan bersilaturahmi ke rumah sanak saudara dan tetangga untuk menikmati lemang yang sudah disediakan oleh tuan rumah.

\section{Kondisi Psikis yang muncul}

Berdasarkan hasil wawancara yang penulis lakukan, terdapat beberapa hal yang dapat penulis gambarkan.

Hasil wawancara 1

Nama : Bahrul (50 tahun), Mahya (70 tahun), Nuraini (67 tahun)

Pertanyaan :

1. Apa yang Bapak/Ibu ketahui tentang kegiatan membakar Tunam dan melemang pada saat malam Nujuh Likur?

Jawaban:

"Aee, tahu aku. Tunam tu mbaka' sayak yang lah disusun ninggi. kami nyaka' sayak sebayak-bayak_an, sesape yang paling bayak ndapatkan sayak bangga liwaat,aku dulu pernah dikeja' anjing ulih ndapatkan sayakngan kekawanku.. hahah.. Kalu ngelemang tu kalu kami jaman dulu masih se'ing ngelemang, sesame tetangge kelua' 'umah ngelemang di depan 'umah, 'adu tu manjaui ke'umah tetangge saling silaturahmi" (Bahrul, 50 tahun).

Dapat penulis jabarkan maksud dari jawaban partisipan sebagai berikut:
"Iya, saya tahu tunam itu membakar batok kelapa yang sudah disusun tinggi. Kami mencari batok kelapa sebanyakbanyaknya.Siapa saja yang mendapatkan batok kelapa paling banyak akan sangat bangga sekali, dahulu saya pernah dikejar anjing untuk mendapatkan batok kelapa bersama-sama dengan teman-teman saya. Hahaha... (tertawa). Kalau melemang itu, pada zaman kami dahulu masing-masing buat melemang, bersama-sama tetangga keluar rumah ngelemang di depan rumah, setelah itu saling mengunjungi ke rumah tetangga untuk bersilaturahmi (Bahrul 50 Tahun)

Pada partisipan yang kedua jawabannya sebagai berikut:

"Jaman dulu, kalu de mbuat tunam tu maluan ngan kekawan sebelah 'umah. Asal muasalnye tu ka'ne dulu de nye lampu, itulah ngape kami masang tunam untuk bejalan ke tempat-tempat pemandian, 'adu tu ha'ang nye tu ulih ndak nggosok baju sesiap ndak sholat id. (Mahya, 70 Tahun) $)^{10}$

Dapat penulis jabarkan maksud dari jawaban partisipan sebagaiberikut: "Zaman dahulu, kalau tidak membuat tunam akan merasa malu dengan teman-teman sebelah rumah (tetangga). Asal usul tunam karena dahulu tidak ada lampu, oleh karena itu kami memasang tunam untuk berjalan ke tempat pemandian, setelah itu arang dari batok kelapa dijadikan sebagai isian batu gosok untuk menggosok baju persiapan sholat idul fitri (Mahya, 70 Tahun).

"Pas malam 26 tu kami ngelemang, nah pas tanggal 27 nye tu kami mbaka' tunam. Dulu pas kami masih 'enik, 'iang liwat nyaka' sayak di tempat-tempat sampah, pinggi' jalan, bekas u'ang nguku' kelape. Jaman itu masih jadi permainan untuk bebudak. Saya' yang lah dapat tu langsung dibolongi 'adu tu kami ikat ngan tali repia, 
'adu tu belari-belari sampai sayak tu bebunyi-bunyi di jalan. Kadang juge kami numpang ke 'umah tetangge ndak mintak sayak, kadang de di njuk nyee". (Nuraini, 67 tahun $)^{11}$

Dapat penulis jabarkan maksud dari jawaban partisipan sebagai berikut: "Saat malam ke 26 itu kami melemang, ketika tanggal 27 nya kami membakar tunam. Dahulu saat kami masih kecil, riang (senang) sekali mencari batok kelapa di tempat-tempat sampah, pinggir jalan, sisa orang mengeruk daging kelapa. Zaman itu mencari batok kelapa menjadi salah satu permainan untuk anak-anak. Batok kelapa yang sudah didapatkan kemudian dilubangi bagian tengahnya setelah itu diikat dengan tali rapia, setelah itu sambil berlari-lari hingga sayak berbunyibunyi di jalanan. Terkadang juga kami meminta ke rumah-rumah tetangga untuk mendapatkan batok kelapa, kadang tidak diberi. (Nuraini, 67 Tahun).

\section{Hasil Wawancara 2}

Subjek : Siswa-Siswa Kelas 8 (usia 15 Tahun) Lokasi : MtsN Kaur

Pada wawancara kedua ini penulis tidak melakukannya secara personal, akan tetapi penulis melakukan tanya jawab secara global dan spontanitas dengan pertanyaan "Apakah kalian mengetahui apa itu malam nujuh likur, Tunam, dan ngelemang?" Jawaban yang penulis peroleh adalah "kami de tahu same sekali" yang artinya "Kami tidak tahu sama sekali". Hal ini diperkuat dengan gestur dan ekspresi ketidaktahuan mereka terhadap istilah "term" tersebut. Berselang beberapa saat, penulis menggambarkan seperti apa wujud/bentuk tunam itu sendiri. Penulis menjelaskan bahwa "Apakah kalian pernah melihat di akhir bulan puasa? Di setiap rumah ada sayak-sayak yang disusun kemudian dibakar?" Sontak siswa-siswa menjawab "aaaeeee, tahuu..tahuuu... oо name ee tunam, de tahu kami name e, tapi kami rutin setiap tahun mbuati itu."12 Dapat penulis artikan "oyaa, kami tahu, oo namanya tunam ya kami tidak tahu namanya, tetapi kami rutin membuatnya setiap satu tahun sekali". Setelah itu penulis mengajukan pertanyaan lanjutan.

Pertanyaan:

"Apa penyebab kalian tidak mengetahui istilah tersebut, padahal kalian rutin membuatnya?"

Jawaban siswa-siswa tersebut penulis rangkum sebagai berikut:

a. Kurang paham tentang budaya tersebut.

b. Sedari kecil orang tua mereka tidak menjelaskan tentang istilah tersebut.

c. Hanya ikut-ikutan saja tanpa memahami maksud dari tradisi tersebut.

Berdasarkan jawaban siswa-siswa di atas dapat penulis jelaskan bahwa tradisi turun temurun yang dilakukan hanya dilakukan karena konformitas, mereka tidak mengetahui makna dari tradisi tersebut. Penyebabnya adalah orang tua yang tidak mengenalkan budaya/tradisi tersebut.

\section{Hasil wawancara 3}

Lokasi : Kantor Lurah Tanjung Iman

Subjek : Pak Lurah dan Staf

Pertanyaan:

“Silakan ceritakan apa saja yang Bapak/ ibu rasakan ketika membakar tunam dan melemang di malam penghujung bulan Ramadhan (27 Ramadhan)?"

Jawabannya dapat penulis rangkum sebagai berikut: ${ }^{13}$

1. "Senang ngenginak bebudak nyaka' 'adu tu nyusun sayak"

(Senang melihat anak-anak mencari dan menyusun batok kelapa) 
Lailatul Badriyah

Empati dalam Tradisi Membakar "Tunam" dan "Melemang"

2. “Te'ase lah ndak njelang ha'i raye, pe'asean tu enggebu-gebu"

(Terasa suasana menjelang hari raya idul fitri, perasaan senang yang menggebugebu)

3. "Ngelemang mbuat hati tent'am ka'ne bekumpul ngan ke'abat, sanak kelu'age"

(Ngelemang membuat hati tentram karena berkumpul dengan kerabat, sanak keluarga)

4. "Sedih lah ndak habis bulan puase, ntah pacak betemu lagi ape de taun depan."

(Perasaan sedih karena bulan puasa sebentar lagi akan berakhir, apakah bisa bertemu lagi pada tahun berikutnya)

5. "Ade sebagian ngicikkan kalu ngidupkan tunam supaye roh nenek moyang de salah 'umah, ka'ne ade yang berkeyakinan roh yang lah mati ndak ngumpul ngan anak cucunye".

(Beberapa orang berkata bahwa membakar tunam agar roh nenek moyang tidak salah memasuki rumah, karena ada yang percaya bahwa roh orang yang sudah meninggalingin berkumpul kembali dengan anak cucu mereka)

Peneliti melakukan wawancara kepada partisipan yang berusia 15-80 tahun. Berdasarkan wawancara tersebut, dapat penulis identifikasi beberapa hal terkait dengan unsur-unsur psikologis yang muncul antara lain dapat penulis jelaskan melalui tabel di bawah ini:

\begin{tabular}{|c|c|c|}
\hline No & $\begin{array}{c}\text { Kondisi } \\
\text { Psikologis } \\
\text { Yang Muncul }\end{array}$ & Kutipan \\
\hline 1 & $\begin{array}{ll}\text { Rasa } & \text { Malu } \\
(\text { shame) } & \end{array}$ & $\begin{array}{l}\text { Jaman dulu, kalu de } \\
\text { mbuat tunam tu } \\
\text { maluan } \\
\text { kekawan ngan } \\
\text { 'umah }\end{array}$ \\
\hline 3 & $\begin{array}{l}\text { Semangat } \\
\text { (enthusiastic) }\end{array}$ & $\begin{array}{l}\text { Saya' yang lah dapat } \\
\text { tu langsung } \\
\text { dibolongi 'adu tu } \\
\text { kami ikat ngan tali } \\
\text { repia, 'adu tu belari- }\end{array}$ \\
\hline
\end{tabular}

\begin{tabular}{|c|l|l|} 
& & $\begin{array}{l}\text { belari sampai sayak } \\
\text { tu bebunyi-bunyi di } \\
\text { jalan. }\end{array}$ \\
\hline 4 & $\begin{array}{l}\text { Memunculkan } \\
\text { Kebanggaan } \\
\text { Diri } \\
\text { esteem) }\end{array}$ & $\begin{array}{l}\text { kami nyaka' sayak } \\
\text { sebayak-bayak_an, } \\
\text { sesape yang paling } \\
\text { bayak ndapatkan } \\
\text { sayak bangga liwaat }\end{array}$ \\
\hline 5 & Ingatan Masa & \begin{tabular}{l} 
aku dulu pernah \\
\hline
\end{tabular} \\
\hline
\end{tabular}

\begin{tabular}{|c|c|c|}
\hline & lalu (memories) & $\begin{array}{l}\text { dikeja' anjing ulih } \\
\text { ndapatkan sayak } \\
\text { ngan kekawanku.. } \\
\text { hahha }\end{array}$ \\
\hline 6 & $\begin{array}{l}\text { Kebahagiaan } \\
\text { (happiness) }\end{array}$ & $\begin{array}{l}\text { - Karena melihat } \\
\text { anak-anak } \\
\text { semangat dalam } \\
\text { mencari sayak } \\
\text { dan } \\
\text { menyusunnya } \\
\text { menjadi tunam } \\
\text { - Karena perasaan } \\
\text { yang menantikan } \\
\text { datangnya hari } \\
\text { raya idul fitri } \\
\text { yang sebentar } \\
\text { lagi hanya } \\
\text { menghitung hari. }\end{array}$ \\
\hline 7 & $\begin{array}{l}\text { Kebersamaan } \\
\text { (communicated) }\end{array}$ & $\begin{array}{l}\text { Makna tentang } \\
\text { berkumpul } \\
\text { bersama, saling } \\
\text { bertukar cerita, } \\
\text { interaksi sosial } \\
\text { yang kuat }\end{array}$ \\
\hline 8 & $\begin{array}{l}\text { Kecemasan } \\
\text { (anxiety) }\end{array}$ & $\begin{array}{l}\text { Terdapat } \\
\text { ketakutan dan } \\
\text { kecemasan tentang } \\
\text { masa akan datang } \\
\text { dapat bertemu lagi } \\
\text { dengan bulan } \\
\text { Puasa }\end{array}$ \\
\hline 9 & $\begin{array}{l}\text { Persepsi } \\
\text { tentang mitos } \\
(\text { fantasy })\end{array}$ & $\begin{array}{l}\text { Terdapat mitos } \\
\text { yang berkembang } \\
\text { tentang fungsi } \\
\text { membakar tunam }\end{array}$ \\
\hline
\end{tabular}


Dapat penulis jelaskan bahwa kondisi psikologis yang muncul dari hasil wawancara tersebut ada rasa malu, senang, semangat, kebanggaan diri, dan ingatan masa lalu yang menyenangkan serta persepsi tentang mitos. Dilihat dari cara (ekspresi/ raut wajah) partisipan ketika menjawab pertanyaan, menunjukkan kondisi yang sinkron dengan apa yang diperlihatkan. Ketika menjawab pertanyaan, partisipan terlihat sangat antusias,salahsatuyangmenjawab, partisipan yang lain akan langsung menambahkan jawaban yang makin luas, sehingga penulis mendapat banyak informasi yang saling berkesinambungan.

Adapun hasil penelitian kepada siswa MTsN (usia 15 tahun) dapat dijelaskan sebagai berikut:

a) Kurang paham tentang budaya tersebut

b) Sedari kecil orang tua mereka tidak menjelaskan tentang istilah tersebut

c) Hanya ikut-ikutan saja tanpa memahami maksud dari tradisi tersebut.

Berdasarkan jawaban siswa-siswa di atas dapat penulis jelaskan bahwa tradisi turun temurun yang dilakukan hanya dilakukan karena konformitas, mereka tidak mengetahui makna dari tradisi tersebut penyebabnya adalah orang tua yang tidak mengenalkan budaya/tradisi tersebut.

\section{Kajian Hermeneutika tentang Tradisi Membakar Tunam dan Melemang}

Berdasarkan data yang didapat dari lapangan, masyarakat memahami tunam sebagai alat penerangan yang hanya di buat saat malam 27 Ramadhan (nujuh likur). Zaman dahulu tidak ada penerangan listrik seperti saat ini, jadi masyarakat menggunakan media berupa obor api bersumbu, termasuk tunam (susunan batok kelapa). Selain menyalakan tunam, ada tradisi melemang, yaitu membuat sebuah makanan yang berasal dari ketan. Lemang lebih dianggap sebagai makanan yang melambangkan kemeriahan dan hubungan silaturahim antara sesama manusia, karena Lemang memiliki tekstur yang lengket dan diasumsikan mampu mempererat hubungan antar sesama manusia.

Tunamdanlemangmerupakanduakegiatan yang memiliki unsur yang sama yaitu proses yang dilakukannya sama-sama dibakar. Api merupakan simbol keberanian, keangkuhan, kebesaran, persaudaraan, pergerakan, serta pengorbanan. Api juga memberikan arti sesuatu yang berkuasa, rasa emosi, egois, apatis, serta semangat yang berkobar. Jika dikaitkan dengan pembakaran tunam, api dapat membakar esensi terdalam dari sifatsifat jelek manusia seperti kesombongan dan keangkuhan. Sedangkan Lemang yang sarat akan kebaikan, penuh kelekatan dan persaudaraan harus dibakar agar semakin mempererat dalam hubungan interpesonal yang lebih baik dan lebih berkualitas.

Dalam mengkaji makna kedua istilah tersebut, penulis mencoba menggunakan susunan piramida hermeneutika oleh Saidi (2008). Adapun kerangka metodologis hermeneutika dapat dilihat pada gambar di bawah ini:

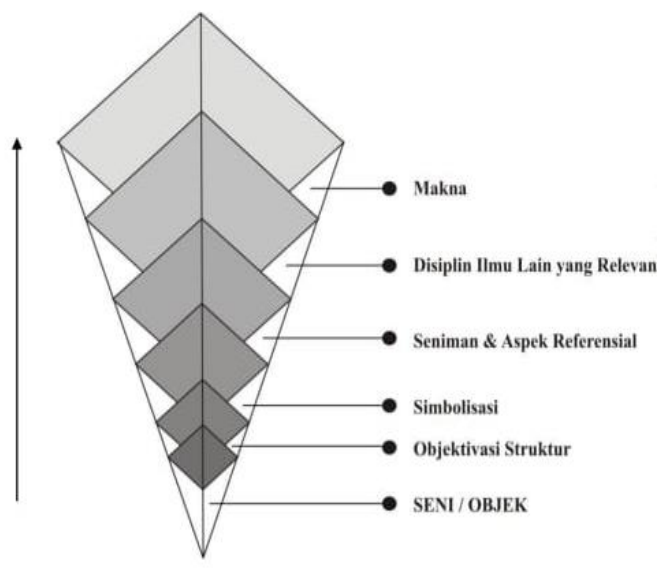

Gambar 2. Metodologi Pengkajian Hermeneutika ${ }^{25}$ 


\section{Kerangka Model Empati berbasis Tra- disi Tunam dan Lemang}

Setelah proses penelitian dilakukan, maka peneliti mencoba membuat sebuah kerangka model empati sebagai berikut:

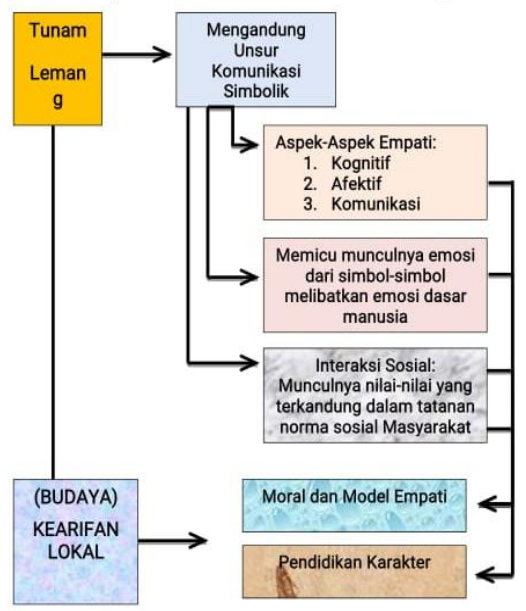

\section{DISKUSI}

Secara garis besar para ahli psikologi membagi empati berdasarkan tiga komponen yaitu komponen kognitif, afektif, dan komunikasi.

Komponen kognitif merupakan komponen yang melibatkan pemahaman, cara berpikir, membayangkan, dan mempersepsikan secara mental kondisi atau hal-hal yang dapat menimbulkan perasaan terhadap sesuatu. Hasil penelitian menunjukkan kondisi psikologi yang muncul berupa ingatan-ingatan masa lalu (memories), dan persepsi tentang cerita-cerita mitos yang berkembang di masyarakat (fantasy), yang memunculkan kesan mendalam, sehingga tradisi tersebut dahulunya sangat dinantinanti.

Komponen afektif merupakan komponen yang menitikberatkan pada perasaan (feeling), antara individu terhadap suatu kondisi. Hasil penelitian menunjukkan efek yang muncul adalah rasa malu (shame), rasa bahagia (happiness), semangat (enthusiastic), kebanggan diri (self esteem), serta kecemasan (anxiety) yang berorientasi pada diri pribadi. Melemang memicu untuk merasakan pengalaman menyenangkan untuk saling tolong menolong, keakraban dengan sesama tetangga, teman dekat bahkan keluarga.

Rasamalu didefinisikansebagai (shyness) merupakan ketidaknyamanan individu atas kondisi yang sedang dihadapi. Rasa malu terjadi saat seseorang tidak melakukan suatu perilaku yang menjadi kepentingan terbaik mereka sendiri, hal itu karena merasa takut bahwa hasilnya akan negatif. Shyness dapat dideskripsikan juga sebagai rasa cemas atau canggung, saat seseorang berada di suatu situasi baru atau didekati oleh orang lain yang tidak dikenal. Salah satu contoh gejala yang tampak pada masing masing tingkatan seperti pada tingkat kognisinya yaitu takut terhadap evaluasi negatif dan terlihat bodoh di depan orang lain. Orang yang memiliki rasa malu akan berpikir bahwa dirinya lemah, sebaliknya orang yang lain memiliki power atau kuat.

Pada tingkat afeksi gejala yang muncul antara lain perasaan malu, self-esteem rendah, cemas, depresi, dan sebagainya. Muka memerah, berkeringat, merasa pusing, gemetaran, dan jantung berdetak cepat merupakan gejala yang tampak jika dilihat dari fisiknya. Orang pemalu juga akan melakukan perilaku yang tampak tidak nyaman jika melakukan interaksi dengan orang lain, seperti berbicara sangat pelan, melakukan kesalahan dalam berbicara (bicara terlalu cepat atau tibatiba tidak bisa mengeluarkan kata-kata), dan lain sebagainya.

Terdapat dua jenis shyness yaitu situational (state) shyness dan dispositional (trait) shyness. Situational shyness melibatkan emosi dan kognisi yang merupakan pengalaman dari rasa malu itu sendiri. Tipe ini dapat terjadi sewaktu-waktu oleh siapapun, terutama pada suatu situasi sosial.Sedangkan dispositional shyness merupakan malu yang 
bersifat jangka panjang atau permanen walaupun dalam waktu maupun situasi yang berbeda. ${ }^{27}$

Dari hasil penelitian menunjukkan bahwa rasa malu muncul saat tidak berpartisipasi dalam kegiatan membakar tunam dan melemang, tetapi saat ini perasaan malu itu terkikis karena setiap rumah sudah memiliki penerangan berupa lampu. Dahulu ketika tidak membakar tunam dan Melemang serasa malu karena nanti orang lain akan beranggapan negatif, dianggap tidak mampu dan sebagainya.

Perasaan senang yang muncul diidentifikasikan sebagai respon yang positif untuk menantikan pergantian pada hari raya Idul Fitri. Penelitian dari Milla, Faizuddin \& Abdallah menemukan bahwa kebahagiaan yang bersumber dari empati secara signifikan dapat mengurangi iri hati atau dengki. Ketika malam nujuh likur tiba secara otomatis kegiatan membakar tunam dilaksanakan dan melemang juga dilaksanakan. Muncul perasaan hati yang tenang dan tentram karena setiap orang saling bertemu dan bersilaturahmi serta saling mendoakan. Budaya seperti ini membangun sebuah model karakter yang baik dalam membentuk perilaku empati antara satu dengan yang lainnya. ${ }^{28}$

Komponen komunikasi merupakan komponen yang menjembatani antara komponen kognitif dan afektif. Hasil penelitian menunjukkan kondisi psikologis yangmemunculkankomunikasi.Komunikasi muncul karena adanya interaksi sosial yang kuat dalam membangun kebersamaan pada tradisi tersebut. Menurut Cotton empati tidak hanya sekedar kemampuan afektif untuk berbagi perasaan (sharing feeling) dan kemampuan kognitif untuk memahami kondisi orang lain, akan tetapi individu memiliki kemampuan berkomunikasi secara verbal dan nonverbal dalam mengungkapkan empati tersebut..$^{29}$

Munculnya empati karena ada unsur persahabatan, kedekatan antara satu dengan yang lainnya. Ulfah menuliskan terdapat tiga aspek dalam persahabatan yaitu: Friendship's affective (kasih sayang dalam persahabatan) ditandai dengan berbagi perhatian dan perasaan pribadi (seperti pengungkapan diri) dan eksplorasi yang berhubungan dengan lainnya seperti intimasi, apresiasi, dan perhatian (termasuk hormat dan perasaan kehangatan, perhatian, dan cinta). Selanjutnya, persahabatan dijelaskan sebagai pemberi dukungan, dukungan emosi, empati, dan mendukung konsep diri, dimana semuanya mungkin dibuat dengan dasar kejujuran, kesetiaan, dan komitmen. Shared and communal (berbagi dan berkumpul) berpartisipasi dalam kegiatan bersama, kesamaan, dan memberi, serta menerima bantuan bukan berbentuk dukungan afektif. Sociability element (elemen sosial) teman merupakan sumber hiburan, kesenangan, dan rekreasi. ${ }^{4}$

Davis menguraikan empat konstruk empati dalam satu episode empati yang terangkum dalam sebuah proses empati yaitu antecedents, processes, intrapersonal outcomes, interpesonal outcomes. Keempat konstruk tersebut kemudian diuraikan lagi menjadi empat aspek multidimensional, perspective taking dan fantasy mewakili kognitif, serta empathic concern dan personal distress mewakili afektif.

a. Antecedents ialah kondisi-kondisi awal dari individu yang memiliki kapasitas kecenderungan berempati secara natural, dilatarbelakangi oleh faktor biologis (biological capabilities), mempelajari cerita (learning story), dan perbedaanperbedaan individual (individual differences) sehubungan dengan ketertarikan individu untuk berempati. Jika dikaitkan dengan hasil penelitian, antecedents berupa ketertarikan subjek ketika peneliti membahas tentang tunam dan melemang. Terlihat perbedaan tang-gapan antara subjek dari rentang usianya. Subjek 


\section{Lailatul Badriyah \\ Empati dalam Tradisi Membakar "Tunam" dan "Melemang"}

siswa MTs terlihat kebingungan dengan istilah tersebut, sedangkan subjek dengan usia yang lebih matang sangat antusias ketika mendengar istilah tunam dan melemang. Hal yang sama diungkapkan oleh Hoffman yang mengungkapkan salah satu yang menjadi pembangkit empati yaitu Preverbal. Preverbal adalah hubungan langsung pada isyarat-isyarat dari orang lain berupa situasi yang mengingatkan individu pada pengalaman-pengalaman masa lalu yang memunculkan perasaan-perasaan (feelings) baik itu perasaan positif maupun negatif. Isyarat yang dimaksudkan ialah tunam dan melemang yang menjadi pencetus dari munculnya ingatan-ingatan dan perasaan akan masa lalu.

b. Processes ialah mekanisme-mekanisme yang terjadi berdasarkan tiga jenis proses yaitu non-cognitive, simple cognitive dan advanced cognitive. Ketiga jenis proses tersebut memiliki tingkatan yang berbeda. Proses pertama ketika empatiterjadikarena prosesnonkognitif artinya tanpa memerlukan pemahaman terhadap situasi yang terjadi, termasuk di dalamnya ialah reaksi dasar (primary circular reaction) dan gerakan mimikri (motor mimicry). Proses kedua simple cognitive artinya sedikit memerlukan pemahaman terkait kondisi atau situasi yang muncul, termasuk di dalamnya ialah stimulus yang terkondisi (classical conditioning), hubungan langsung antara individu sebagai observer terhadap kondisi (direct association) dan memberikan label (labeling) dengan mendiskriminasi emosi (emotion discrimination) terhadap situasi yang terjadi. Proses ini tidak memerlukan pemahaman yang mendalam karena kondisi yang muncul merupakan kondisi normal yang sering dialami. Proses ketiga advanced cognitive artinya individu mengerahkan kemampuan kognitifnya secara mendalam dengan cara memahami ucapan atau bahasa yang disampaikan oleh orang tersebut (target) yang disebut dengan language mediated assosiations, termasuk di dalamnya ialah menggabungkan kognitif (elaborated cognitive network) dan memahami orang lain dari sudut pandang orang tersebut (role taking/perspective taking). Proses ini memerlukan upaya yang ekstra karena empati akan berbeda antara individu dengan individu lainnya berdasarkan kemampuannya dalam memahami pikiran dan kondisi yang dialami orang lain. Pada tahapan proses ini, terdapat tiga komponen yaitu kognitif, afektif, dan komunikasi yang berperan aktif dalam pembentukan respon-respon setelahnya. Dari hasil penelitian, terlihat ada dua kondisi psikologis yang termasuk pada komponen kognitif yaitu memories dan fantasy, karena untuk memunculkan kondisi tersebut membutuhkan pemahaman yang mendalam.

c. Intrapersonal outcomes yaitu respon emosional terhadap kondisi yang terjadi yang dialami oleh orang lain, dalam memberikan respon tersebut mungkin emosi keduanya tidak secara langsung bertemu, tetapi lebih kepada berbagi emosi yang senada, hal tersebut termasuk di dalamnya empathic concern (simpati), anger, dan personal distress.

Hasil penelitian terhadap remaja siswa di MTs Negeri Kaur menunjukkan telah terkikisnya tradisi membakar tunam dan Melemang. Mereka secara simbolik berupa artefak (wujud benda) mengetahui tunam, akan tetapi ketika ditanya secara istilah mereka tidak mengetahui dan tidak dapat menjelaskan maknanya. Secara psikologi perkembangan, tahapan usia remaja berada pada kondisi pergantian moralitas dari konsep-konsep moral khusus ke konsep 
moral individual. ${ }^{30}$

Selama berada dalam keadaan tersebut, remaja mengalami ambiguitas dalam pola berpikir kognitif dan respon afektif sebagai pengarah kepada perilaku yang akan ditampilkan. Salah satu contoh ambiguitas yang dialami remaja adalah mencari identitas diri. Menurut teori Psikososial Erikson, remaja berada di tahap V yaitu identity vs identify confusion (identitas vs kebingungan identitas), menurut Erikson jika remaja menerima dukungan sosial yang memadai, maka akan muncul eksplorasi personal, kepekaan diri, perasaan mandiri, dan kontrol diri. Begitu juga sebaliknya, remaja yang tidak yakin terhadap kepercayaan diri dan sering kali mendapatkan penolakan dari orang tua, maka dapat dipastikan remaja tersebut akan terus mengalami kebingungan. ${ }^{31}$

Kebingungan-kebingungan inilah yang berdampak pada ketidakstabilan emosi yang akan menimbulkan konflik. Konflik internal antara remaja dan orang tua mempengaruhi perkembangan empatinya. Dengan kata lain, semakin banyak konflik yang muncul akan membuat empati semakin rendah. ${ }^{32}$ Menurut Carr emosi itu timbul jika individu dihadapkan pada rintangan yang menghambat kebebasannya untuk bergerak, sehingga semua tenaga dan upaya dikerahkan untuk mengatasi rintangan tersebut dan merangsang individu tersebut untuk merugikan lawannya tanpa pertimbangan terlebih dahulu. ${ }^{33}$

\section{Kesimpulan}

Penelitian empati berbasis budaya menunjukkan bahwa banyak nilai-nilai positif dari tradisi membakar tunam dan melemang saat malam nujuh likur pada masyarakat Kabupaten Kaur. Unsur kognitif seperti mengingat akan halhal yang berkesan akan memicu emosi (perasaan) senang yang mendalam, hati yang tentram, rasa malu dan rasa sedih.
Ketika seseorang mampu menunjukkan emosi yang positif terhadap orang lain, maka akan memunculkan istilah (empathic concern).

Tunam dan lemang dianggap sebagai media komunikasi yang menimbulkan interaksi simbolik, karena kegiatan ini sangat unik yang dilakukan setiap tahun pada malam Nujuh Likur (27 Ramadhan). Akan tetapi dalam perkembanganya, tradisi tersebut mulai terkikis. Hal ini diasumsikan bahwa akan sangat sulit bagi generasi muda untuk mendalami makna atau hakikat dari budaya disekitarnya yang dapat membentuk karakter yang baik dan berkualitas.

Bagi penelitian selanjutnya diharapkan melakukan penelitian di tempat yang lebih mendalam. Penulis mendapat info kalau di daerah kaur tepatnya di Desa Babat, masyarakat masih kental menjaga tradisi turun temurun yaitu membakar tunam dan melemang. Karena keterbatasan waktu dan cakupan penelitian, maka penulis menyarankan untuk meneliti secara lebih mendalam.

\section{Referensi}

Ahmadi, D., Interaksi Simbolik: Suatu Pengantar. MEDIATOR, 9(2), 2008.

Arikunto, Prosedur Penelitian Suatu Pendekatan Praktek. Jakarta : PT. Rineka Cipta, 2006.

Basyari, I.W, Nilai-Nilai Kearifan Lokal (Local Wisdom) Tradisi Memitu Pada MasyarakatCirebon(Studi Masyarakat Desa Setupatok Kecamatan Mundu). Edunomic Jurnal Pendidikan Ekonomi, 2(1), (2014): 48-56.

Ernatip,Ungkapan Tradisional Masyarakat Kaur Yang Berkaitan Dengan Pendidikan. Padang: Balai Pelestarian Sejarah Dan Nilai Tradisional, 2011.

Garton, A.F., \& Gringart, E., The development of a scale to measure empathy in 8and 9-year old children. Australian 
Journal OfEducation and Developmental Psychology, 5,(2005): 17-25.

Hartati, N., Nihayah, Z., Shaleh, A.R., \& Mujib, A,Islam dan Psikologi. Jakarta: RajaGrafindo Persada, 2005.

Hoffman, M.L,Empathy and moral development: implications for caring and justice. New York: Cambridge University Press, 2000.

Howe, D., Empati: Makna dan Pentingnya. (Ahmad Lintang Lazuardi, Terj). Yogyakarta: Pustaka Pelajar, 2015.

Kistanto, N.H., Tentang Konsep Kebudayaan. Sabda: Jurnal Kajian Kebudayaan, 10(2), (2015).

Kusumasari, H., \& Hidayati, D.S., Rasa Malu dan Presentasi Diri Remaja di Media Sosial. Jurnal Psikologi Teori E Terapan, 4(2),(2014): 91 - 105, ISSN: 2087-1708.

Milla, S.N., Faizuddin, A., \& Abdallah, S.S.,Empathetic Joy (Expressing Happiness Towards Others' Fortune) to Reduce Hassad Tendency Among Muslim Students. Presented at the 2nd International Conference on Islamic Psychology (ICONIPSY) Yogyakarta, Indonesia, 2015.

Nurhasanah, I.,Be'eduk Pada Tari Adat Dalam Bimbang Pernikahan Masyarakat Bintuhan Kabupaten Kaur (Skripsi tidak terpublikasi) Universitas Bengkulu, Bengkulu, 2019.

Saidi, A.I., Hermeneutika, Sebuah Cara Untuk Memahami Teks. Jurnal Sosioteknologi, 13(7),(2008): 376-382

Santrock, J.W.,Life-Span Development: Perkembangan Masa Hidup (Edisi Kelima). (Achmad Chusairi \& Juda Damanik, Terj). Jakarta: Erlangga, 1995.

Sarwono, S.W.,Psikologi Lintas Budaya. Jakarta: Rajawali Pers, 2014

Siregar, N.S.S., Kajian Tentang Interaksionisme Simbolik. Perspektif: Jurnal Ilmu Sosial-Fakultas ISIPOL UMA, 4(2),(2011): 100-110.
Taufik,Empati pendekatan psikologi sosial. Jakarta: Rajawali Pers, 2012.

Ulfah, J.M., Memahami Perilaku Empati Komunikasi Antar Pribadi Dalam Persahabatan Di Jejaring Sosial Path (Skripsi yang tidak terpublikasi). Universitas Diponegoro, Semarang, 2015.

Lissa, C.J.V, Hawk, S.T., Branje, S.J.T., Koot, H.M., Van Lier, P.A.C., \& Meeus, W.H.J., Divergence between adolescent and parental perceptions of conflict in relationship to adolescent empathy development. J Youth Adolescence. Doi, (2014):: 10.1007/s10964-014-0152-5

Zuchdi, D., \& Afifah, W.,Analisis Konten Etnografi \& Grounded Theory Dan Hermeneutika Dalam Penelitian. Jakarta: Bumi Aksara, 2019.

\section{Catatan Akhir}

${ }^{1}$ Hoffman, Empathy and moral development: implications for caring and justice, 250.

2Sarwono, Psikologi Lintas Budaya, 79.

${ }^{3}$ Howe, Empati: Makna dan Pentingnya.

(Ahmad Lintang Lazuardi, Terj), 234.

${ }^{4}$ Kistanto, Tentang Konsep Kebudayaan,

8

${ }^{5}$ Kistanto, Tentang Konsep Kebudayaan, 10

${ }^{6}$ Basyari, Nilai-Nilai Kearifan Lokal (Local Wisdom) Tradisi Memitu Pada Masyarakat Cirebon (Studi Masyarakat Desa Setupatok Kecamatan Mundu), 50.

${ }^{7}$ Howe, Empati: Makna dan Pentingnya. (Ahmad Lintang Lazuardi, Terj), 300

${ }^{8}$ Taufik, Empati pendekatan psikologi sosial, 103.

${ }^{9}$ Ahmadi, Interaksi Simbolik: Suatu Pengantar, 310.

${ }^{10}$ Siregar, Kajian Tentang Interaksionisme Simbolik, 106.

${ }^{11} \mathrm{Ahmadi}$, Interaksi Simbolik: Suatu Pengantar, 313. 
Tsaqufah \& Tarikh: Jurnal Kebudayaan dan Sejarah Islam

Vol. 5 No. I Januari-Juni 2020

${ }^{12}$ Ashsubli, Islam dan Kebudayaan Melayu Nusantara (Menggali Hukum dan Politik Melayu dalam Islam), 283-290

${ }^{13}$ Hasanah, Be'eduk Pada Tari Adat Dalam Bimbang Pernikahan Masyarakat Bintuhan Kabupaten Kaur, 56.

${ }^{14}$ Sarwono, Psikologi Lintas Budaya, 77.

${ }^{15}$ Zuchdi \& Afifah, Analisis Konten Etnografi \& Grounded Theory Dan Hermeneutika Dalam Penelitian, 71.

${ }^{16}$ Hasanah, Be'eduk Pada Tari Adat Dalam Bimbang Pernikahan Masyarakat Bintuhan Kabupaten Kaur, 70.

${ }^{17}$ Zuchdi \& Afifah, Analisis Konten Etnografi \& Grounded Theory Dan Hermeneutika Dalam Penelitian, 75.

${ }^{18}$ Hasanah, Be'eduk Pada Tari Adat Dalam Bimbang Pernikahan Masyarakat Bintuhan Kabupaten Kaur, 73.

${ }^{19}$ Hasanah, Be'eduk Pada Tari Adat Dalam Bimbang Pernikahan Masyarakat Bintuhan Kabupaten Kaur, 74.

${ }^{20}$ Kutipan wawancara subjek Bahrul pada tanggal 23 Juli 2019, bertempat di kabupaten Kaur Tengah

${ }^{21}$ Kutipan wawancara subjek Mahya pada tanggal 23 Juli 2019, bertempat di kabupaten Kaur Tengah

${ }^{22}$ Kutipan wawancara subjek Nuraini pada tanggal 24 Juli 2019, bertempat di kabupaten Kaur Tengah
${ }^{23}$ Kutipan wawancara siswa-siswa kelas 7 MtsN Kaur pada tanggal 24 Juli 2019.

${ }^{24}$ Kutipan wawancara Lurah dan staf di Kbupaten Kaur Tengah pada tanggal 25 Juli 2019.

${ }^{25}$ Saidi, Hermeneutika, Sebuah Cara Untuk Memahami Teks, 378.

${ }^{26}$ Kusumasari \& Hidayati, Rasa Malu dan Presentasi Diri Remaja di Media Sosial. 95.

${ }^{27}$ Milla, Faizuddin \& Abdallah, Empathetic Joy (Expressing Happiness Towards Others' Fortune) to Reduce Hassad Tendency Among Muslim Students, 8.

${ }^{28}$ Garton \& Gringart, The development of a scale to measure empathy in 8-and 9-year old children, 20.

${ }^{29}$ Ulfah, Memahami Perilaku Empati Komunikasi Antar Pribadi Dalam Persahabatan Di Jejaring Sosial Path, 8.

${ }^{30}$ Hartati, Nihayah, Shaleh, \& Mujib, Islam dan Psikologi, 32.

${ }^{31}$ Santrock, LifeSpan Development: Perkembangan Masa Hidup (Edisi Kelima), 150.

${ }^{32}$ Lissa dkk, Divergence between adolescent and parental perceptions of conflict in relationship to adolescent empathy development, 50.

${ }^{33}$ Hartati, Nihayah, Shaleh, \& Mujib, Islam dan Psikologi, 40. 